\title{
Perubahan dan prediksi penggunaan/penutupan lahan di Kabupaten Lampung Selatan
}

\section{Change and prediction of land cover/use change in South Lampung Regency}

Rakhman Adhiatma ${ }^{\mathrm{a}}$, Widiatmaka ${ }^{\mathrm{b}}$, Iskandar Lubis ${ }^{\mathrm{c}}$

\footnotetext{
a Program Studi Ilmu Perencanaan Wilayah Sekolah Pascasarjana, Institut Pertanian Bogor, Kampus IPB Darmaga Bogor, 16680, Indonesia [+6282310044374]

${ }^{\mathrm{b}}$ Departemen Ilmu Tanah dan Sumberdaya Lahan, Fakultas Pertanian, Institut Pertanian Bogor, Kampus IPB Darmaga Bogor, 16680, Indonesia

${ }^{\mathrm{c}}$ Departemen Agronomi dan Hortikultura, Fakultas Pertanian, Institut Pertanian Bogor, Kampus IPB Darmaga Bogor, 16680, Indonesia
}

\section{Article Info:}

Received: 10 - 01 - 2020

Accepted: 01 - 06 - 2020

Keywords:

Cellular automata, future prediction, land cover change, spatial model.

\section{Corresponding Author:}

Rakhman Adhiatma

Program Studi Ilmu Perencanaan

Wilayah Sekolah Pascasarjana,

Institut Pertanian Bogor;

Tel. +6282310044374

Email:

rakhman.adhiatma@gmail.com

\begin{abstract}
Land use/cover is one of the important factors in land management. The land use/cover changes can affect the policy in an area. Land use/cover in South Lampung Regency is potentially changed because of economic, social, and populations aspect. This research aimed to analyze the spatial change of land use/cover in the South Lampung Regency period 2007-2019 and to predict land use/cover of 2031. The analysis was carried out applying cellular automata Markov chain of land cover spatial model. The result showed that Kappa for image classification was 0.86. Dominant land cover type in South Lampung Regency was plantation field of 35.47\%-36.18\%. Model validation of 2031 predicted land cover was 0.946, while the types of land cover that increase in 2031 were built-up area and paddy field of $96.8 \%$ and $86.5 \%$, respectively, while paddy fields, forest, moor, the body of water, plantation, shrub decreased approximately $16.2 \%, 14.9 \%, 13 \%, 7.7 \%, 4.1 \%$, and $1.0 \%$. Paddy field that had the most area of decline as prediction results of $16.2 \%$.
\end{abstract}

How to cite (CSE Style $8^{\text {th }}$ Edition):

Adhiatma R, Widiatmaka, Lubis I. 2020. Perubahan dan prediksi penggunaan/penutupan lahan di Kabupaten Lampung Selatan. JPSL 10(2): 234-246. http://dx.doi.org/10.29244/jpsl.10.2.234-246.

\section{PENDAHULUAN}

Perkembangan ekonomi akan dapat meningkatkan pertumbuhan suatu wilayah dengan sangat baik, akan tetapi hal tersebut juga membawa dampak yang negatif salah satunya adalah tingginya permintaan terhadap suatu lahan. Perkembangan ekonomi dan pertumbuhan penduduk juga merupakan menjadi penyebab alih fungsi lahan pertanian menjadi area penggunaan lain selain pertanian. Definisi lahan sendiri menurut Hardjowigeno dan Widiatmaka (2015) adalah suatu lingkungan fisik yang meliputi tanah, iklim, hidrologi, relief dan ekologi lainnya dimana faktor-faktor tersebut mempengaruhi penggunaan lahan tersebut, termasuk di dalamnya adalah akibat-akibat dari kegiatan manusia baik pada masa yang lalu maupun sekarang. Lahan merupakan suatu sumber daya yang sangat terbatas, sehingga permintaan akan lahan yang sangat tinggi akan menimbulkan alih fungsi lahan (perubahan penggunaan lahan), khususnya dari lahan pertanian ke non pertanian (Widiatmaka et al. 2015). Dinamika sosial ekonomi yang terjadi pada masyarakat akan berdampak 
terhadap penggunaan lahan. Ketersediaan lahan yang relatif tetap dapat mengakibatkan persaingan lahan dalam pemanfaatannya dengan konsekuensi terjadinya perubahan penggunaan lahan yang sangat cepat. Dari masa ke masa, lahan telah diubah oleh manusia untuk berbagai jenis penggunaan, diantaranya sawah diubah menjadi lahan terbangun atau lahan non vegetasi (Munibah, 2008). Faktor dominan yang paling dapat merubah suatu tutupan/penggunaan lahan adalah faktor ekonomi dan sosial (Munibah, 2008; Kamusoko et al., 2009). Hal ini dikarenakan kehidupan manusia tidak mungkin terpisahkan dari aspek sosial ekonomi, yaitu dalam usahanya untuk memenuhi kebutuhan hidup.

Berkembangnya Kabupaten Lampung Selatan ini ditandai dengan perkembangan infrastruktur yang baik berupa jalan tol, pemukiman warga maupun infrastruktur lainnya. Pembangunan infrastruktur yang cukup luas melewati wilayah Kabupaten Lampung Selatan dikhawatirkan akan berpengaruh juga terhadap laju konversi lahan padi sawah dan berkurangnya penyediaan pangan di Kabupaten Lampung Selatan. Untuk melihat perubahan penggunaan/penutupan lahan di Kabupaten Lampung Selatan sebelum dan setelah pembangunan infrastruktur perlu dilakukan analisis spasial perubahan penggunaan/penutupan lahan. Saat ini Kabupaten Lampung Selatan belum memiliki peta perubahan penggunaan/penutupan lahan tersebut. Peta perubahan tutupan/penggunaan lahan tersebut agar dapat melihat kondisi sebelum, saat ini dan kondisi yang akan datang serta potensi ketersediaan lahan sawah di Kabupaten Lampung Selatan sampai tahun 2031 sesuai dengan Rencana Tata Ruang Wilayah yang ada.

Verburg et al. (1999) dalam penelitiannya, model spasial dinamis digunakan untuk menganalisis perubahan tutupan/penggunaan lahan yang melibatkan faktor fisik, ekonomi dan sosial. Di dalam penelitian ini, analisis perubahan tutupan/penggunaan lahan dilakukan menggunakan model cellular automata markov chain (CA-Marcov) yang dapat digunakan untuk menganalisis perubahan tutupan/penggunaan lahan dan telah dapat dimanfaatkan secara luas (Hedge et al., 2008; Munibah, 2008; Hermawan, 2011; Wang et al., 2012; Xin et al., 2012; Riccioli et al., 2013; Nouri, 2014; Mondal et al., 2016; Rotinsulu et al., 2018; Yusuf et al., 2018). Model marcov chain ini dipilih karena model ini mampu dan dapat menilai perubahan tutupan/penggunaan lahan baik secara statistis maupun dinamis serta mempertimbangkan faktor antara ruang dan waktu (Hedge $e t$ al., 2008; Jie, 2010; Mondal et al., 2016). Pada model CA-Marcov ini, deteksi perubahan tutupan/penggunaan lahan yang dianalisis didasarkan pada kemungkinan terjadinya perubahan lahan dari suatu kondisi ke kondisi lain berdasarkan aturan lokal, filter spasial cellular automata, dan peta potensial perubahan kemungkinan terjadinya transisi (transition probabilities) (Hedge et al., 2008; Munibah, 2008; Mas et al., 2013). Peta perubahan tutupan/pengguanaan lahan tersebut disusun berdasarkan faktor ketetanggaan dan fisik (lahan) yang memicu terjadinya adanya perubahan tutupan/penggunaan lahan.

Tujuan penelitian ini adalah menganalisis perubahan penggunaan/penutupan lahan di Kabupaten Lampung Selatan, tahun 2007, 2013, dan 2019. Selain itu, juga dilakukan prediksi pengguanaan/penutupan lahan di Kabupaten Lampung Selatan sampai tahun 2031. Tahun 2031 diambil dari berakhirnya masa Rencana Tata Ruang Wilayah Kabupaten Lampung Selatan.

\section{METODE}

\section{Lokasi dan Waktu Penelitian}

Penelitian ini dilakukan di Kabupaten Lampung Selatan yang terdiri dari 17 (tujuh belas) kecamatan. Posisi geografis wilayah penelitian antara $105^{\circ} 14^{\prime}-105^{\circ} 45^{\prime}$ lintang selatan dan $5^{\circ} 15^{\prime}-6^{\circ} 05^{\prime}$, Bujur Timur. Kabupaten Lampung Selatan memiliki batas-batas, yaitu: sebelah barat berbatasan dengan Kabupaten Pesawaran dan Kota Bandar Lampung; sebelah timur berbatasan dengan Laut Jawa; sebelah utara berbatasan dengan Kabupaten Lampung Timur dan Kabupaten Lampung Tengah; sebelah selatan berbatasan dengan Selat Sunda. Luas wilayah Kabupaten Lampung Selatan adalah 2165 km². 


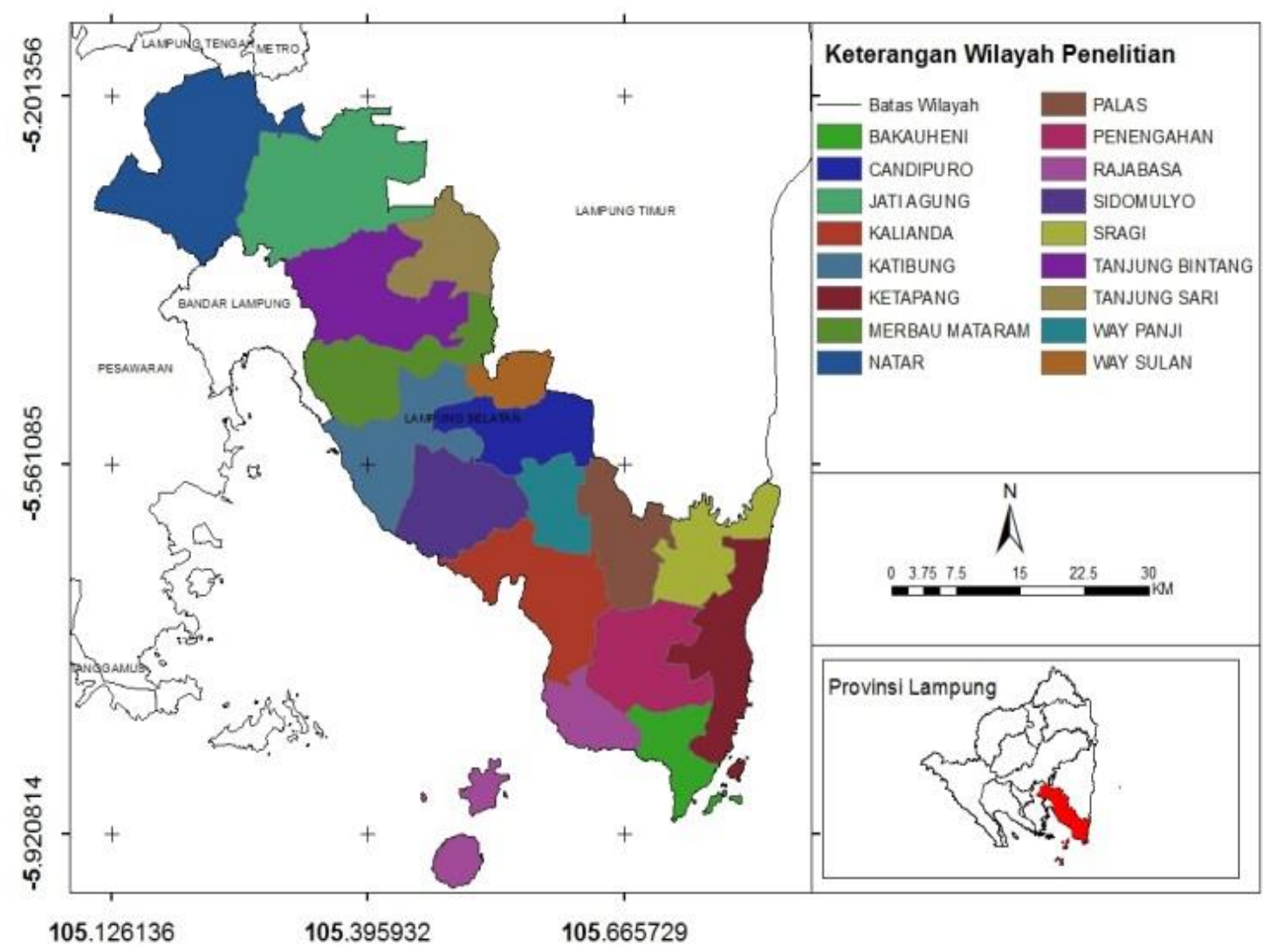

Gambar 1 Lokasi penelitian

\section{Metode Pengumpulan Data}

Data yang dipakai pada penelitian ini adalah citra SPOT 4 Mosaik pada tahun 2007, citra SPOT 6 Mosaik untuk tahun 2013 dan citra SPOT 6 raw data pada tahun 2019 yang diperoleh dari LAPAN serta peta baku sawah yang didapat dari Kementerian ATR/BPN Republik Indonesia dan Peta Rupa Bumi Indonesia (RBI) dari Badan Informasi Geospasial Republik Indonesia.

Alat yang digunakan pada penelitian ini yaitu kamera, perangkat lunak komputer (Microsoft Office, ArcGIS, IDRISI), Global Position System (GPS). GPS dan kamera digunakan untuk dokumentasi kegiatan survei tutupan/penggunaan lahan, ArcGIS merupakan software yang digunakan sebagai alat untuk analisis citra, dan IDRISI merupakan software yang digunakan untuk analisis model perubahan tutupan lahan dengan model CA-Marcov.

\section{Metode Analisis Data}

\section{Tahapan Penelitian}

Penelitian ini dilakukan melalui 2 tahap utama yaitu interpretasi citra dan model prediksi perubahan tutupan/penggunaan lahan yang saling terkait satu sama lain sehingga dihasilkan peta prediksi tutupan/penggunaan lahan tahun 2031.

\section{Interpretasi visual}

Lillesand dan Kiefier (1994) dalam bukunya menyebutkan terdapat 8 (delapan) unsur interpretasi citra yang digunakan secara memusat/konvergen untuk dapat mengenali suatu obyek yang ada pada citra, 8 (delapan) unsur tersebut adalah warna/rona, bentuk, ukuran, bayangan, tekstur, pola, asosiasi dan situs. Acuan sekunder berupa peta lahan baku sawah tahun 2018 yang didapatkan dari Kementerian ATR/BPN, citra satelit 
resolusi tinggi (citra SPOT). Hasil interpretasi kemudian dikelaskan sesuai tipe penggunaan lahan yang ada di wilayah penelitian yaitu Kabupaten Lampung Selatan dan klasifikasi penggunaan/tutupan lahan pada penelitian ini sesuai dengan klasifikasi berdasarkan Standar Nasional Indonesia (SNI) pada tahun 2010.

Verifikasi dan validasi dilakukan untuk mengetahui seberapa besar tingkat kebenaran proses klasifikasi. Verifikasi pada penelitian ini dilakukan dengan cara mengambil titik kenyataan di lapangan (ground check) yang diambil purposive sampling. Validasi hasil klasifikasi dilakukan dengan melakukan uji akurasi. Verifikasi tutupan/penggunaan lahan tahun lampau (tahun 2007 dan tahun 2013) dilakukan melalui metode wawancara informal dengan narasumber yang telah memiliki pengetahuan mengenai kondisi objek yang dijadikan sampel pada masa lampau. Citra resolusi tinggi perekaman terdahulu (archieve) pada Google Earth digunakan pada penelitian ini untuk membantu validasi pada tutupan/penggunaan lahan tahun lampau (tahun 2007 dan tahun 2013).

Setelah dilakukan interpertasi secara visual, uji akurasi klasifikasi pada tutupan/penggunaan lahan dilakukan menggunakan cara perhitungan akurasi secara keseluruhan (overall accuracy) dan menggunakan akurasi kappa berdasarkan matriks kesalahan klasifikasi yang tersaji pada Tabel 1.

Tabel 1 Matriks kesalahan klasifikasi

\begin{tabular}{|c|c|c|c|c|c|c|c|}
\hline \multirow{2}{*}{\multicolumn{2}{|c|}{$\begin{array}{c}\text { Kelas Kemampuan } \\
\text { Lahan }\end{array}$}} & \multicolumn{6}{|c|}{ Referensi } \\
\hline & & $\mathrm{P}_{1+}$ & $\mathrm{P}_{1+}$ & $\mathrm{P}_{1+}$ & $\ldots$ & $\mathrm{P}_{\mathrm{r}+}$ & Jumlah \\
\hline \multirow{5}{*}{ 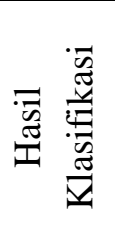 } & $\mathrm{P}_{+\mathrm{i}}$ & & & & & & $\mathrm{X}_{+\mathrm{i}}$ \\
\hline & $\mathrm{P}_{+\mathrm{i}}$ & & & & & & $X_{+i}$ \\
\hline & $\mathrm{P}_{+\mathrm{i}}$ & & & & & & $X_{+i}$ \\
\hline & $\ldots$ & & & & & & $X_{+i}$ \\
\hline & $\mathrm{P}_{+\mathrm{r}}$ & & & & & & $X_{+i}$ \\
\hline \multicolumn{2}{|c|}{ Total kolom } & $\mathrm{X}_{\mathrm{i}+}$ & $X_{i+}$ & $X_{i+}$ & $\mathrm{X}_{\mathrm{i}+}$ & $\mathrm{X}_{\mathrm{i}+}$ & $\mathrm{N}$ \\
\hline
\end{tabular}

Keterangan:

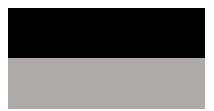

: Piksel yang benar

: Piksel yang salah

Nilai akurasi keseluruhan (overall accuracy) merupakan rasio antara jumlah piksel benar dengan jumlah keseluruhan piksel. Referensi hasil pada penelititan ini sejalan dengan penelitian Liu dan Mason (2009). Nilai pada akurasi keseluruhan (overall accuracy) hanya dengan mempertimbangkan data yang benar antara hasil klasifikasi dan kondisi lapangan (referensi), sehingga nilainya biasanya lebih tinggi daripada nilai akurasi kappa yang mempertimbangkan faktor kesalahan proses klasifikasi. Tingkatan akurasi kappa termasuk kategori yang sangat tinggi jika akurasi kappa bernilai 0.81-1.00 menurut Altman (1991) dalam Kubangun (2015). Rumus perhitungan nilai akurasi keseluruhan (overall accuracy) dan akurasi kappa adalah sebagai berikut:

$$
\text { Overall Accuracy }=\frac{X}{N} \times 100 \%
$$

dengan keterangan untuk overall accuracy sebagai berikut:

$\mathrm{X}$ : Jumlah sampel benar pada penggunaan lahan

$\mathrm{N}$ : Jumlah keseluruhan sampel penggunaan lahan

Sedangkan rumus akurasi kappa adalah sebagai berikut:

$$
K_{\text {hat }}=\frac{N \sum_{i=1}^{r} x_{i i}-\sum_{i=1}^{r}\left(x_{i+}+x_{+i}\right)}{N^{2}-\sum_{i=1}^{r}\left(x_{i+}+x_{+i}\right)}
$$


dengan keterangan sebagai berikut:

$\mathrm{x}_{+\mathrm{i}} \quad$ : Jumlah piksel hasil klasifikasi penggunaan lahan ke- $\mathrm{i}$

$\mathrm{x}_{\mathrm{i+}} \quad$ : Jumlah piksel referensi penggunaan lahan ke -i

$\mathrm{x}_{\mathrm{ii}}$ : Jumlah piksel referensi pada penggunaan lahan ke-i yang sesuai dengan

piksel klasifikasi penggunaan lahan ke- $\mathrm{i}$

i : Baris atau kolom

$\mathrm{r} \quad$ : Jumlah kelas penggunaan lahan

$\mathrm{N}$ : Jumlah pada keseluruhan piksel referensi

$\mathrm{K}_{\text {hat }}$ : Nilai akurasi kappa

\section{Cellular automata (CA) markov}

Perubahan tutupan/penggunaan lahan pada penelitian ini berdasarkan pada peta tutupan/penggunaan lahan sebagai dasar klasifikasi lahan dan kemungkinan perubahan tutupan/penggunaan lahan pada selang waktu tertentu yang dilakukan dengan pendekatan cellular automata (CA). Menurut Chen et al. (2002) komponen utama metode cellular automata $(\mathrm{CA})$ adalah cell (piksel) yaitu merupakan unit dasar spasial dalam ruang seluler, state, ketetanggaan/neighbourhood yang merupakan serangkaian sel yang saling berinteraksi dan transition rule/transition function yaitu bagaimana respon perubahan suatu sel dalam menanggapi kondisi saat ini dan kondisi tetangganya.

Simulasi perubahan tutupan/penggunaan lahan pada penelitian ini dilakukan pada piranti Idrisi dengan modul Cellular Automata Markov (CA-Markov) sesuai dengan penelitian yang dilakukan oleh Munibah (2008). CA-Markov adalah metode yang menggunakan kombinasi dari modul Multi-Objective Land Allocation (MOLA) dan Markov Chain. Masukan dalam model prediksi perubahan tutupan/penggunaan lahan adalah tutupan/penggunaan lahan tahun dasar, matriks transisi perubahan hasil dari modul Markov chain, kesesuaian penggunaan lahan serta filter default sebagai representasi dari fungsi ketetanggaan.

Validasi model pada penelitian ini didasarkan pada nilai akurasi kappa yang memperlihatkan tingkat kecocokan tutupan/penggunaan lahan dari hasil simulasi pada tahun 2007 dengan penggunaan lahan aktual pada tahun 2013. Semakin tinggi nilai akurasi kappa bermakna semakin tinggi tingkat ketepatan dalam tutupan/penggunaan lahan hasil prediksi dengan penggunaan lahan aktual. Prediksi tutupan/penggunaan lahan pada tahun 2019 diperoleh berdasarkan kecondongan perubahan tutupan/penggunaan lahan pada tahun 2007 dan tutupan/penggunaan lahan pada 2013 dengan menjalankan metode menggunakan model simulasi Cellular Automata-Markov (CA-Markov). Masukan pada simulasi prediksi penggunaan lahan tahun 2019 terdiri dari penggunaan lahan tahun 2013 sebagai tahun acuan pertama, kecocokan tutupan/penggunaan lahan dan matriks transisi perubahan tutupan/penggunaan lahan pada tahun 2007 dan tutupan/penggunaan lahan pada tahun 2019 serta filter default $5 \times 5$ pada piranti software Idrisi.

Simulasi model dilakukan pada berbagai iterasi yang menghasilkan peta prediksi tutupan/penggunaan lahan pada tahun 2019 sesuai dengan iterasi yang digunakan. Peta prediksi tutupan/penggunaan pada tahun 2019 yang dihasilkan kemudian akan dibandingkan dengan tutupan/penggunaan lahan pada tahun 2019 aktual untuk mendapatkan peta prediksi dengan nilai akurasi kappa dan dengan jumlah iterasi yang paling optimal. Nilai akurasi kappa tiap iterasi dapat dilihat trennya untuk dapat memastikan pada iterasi berapa terjadi break of slope. Break of slope merupakan titik dimana akan terjadi perubahan yang nyata dan yang paling efektif untuk menjadi pewakil dari jumlah iterasi yang digunakan pada model perubahan tutupan/penggunaan lahan (Munibah 2008). Nilai akurasi kappa dari jumlah iterasi yang terpilih dapat mewakili nilai validasi atau kelayakan dari model yang dibentuk untuk dapat digunakan sebagai model prediksi penggunaan lahan.

Prediksi perubahan tutupan/penggunaan lahan dilakukan untuk mendapatkan gambaran penggunaan lahan wilayah penelitian pada tahun 2031. Masukan dalam simulasi prediksi penggunaan lahan tahun 2031 terdiri dari tutupan/penggunaan lahan pada tahun 2019 sebagai tahun acuan, kecocokan tutupan/penggunaan lahan, filter default 5x5 dan matriks transisi perubahan tutupan/penggunaan lahan antara tahun 2013-2019. 
Proses pengulangan (iterasi) yang digunakan pada simulasi menggunakan nilai iterasi yang paling optimal hasil proses validasi model.

\section{HASIL DAN PEMBAHASAN}

\section{Penggunaan/Penutupan Lahan}

Berdasarkan hasil dari interpretasi citra yang dilakukan, Kabupaten Lampung Selatan mempunyai 8 kelas klasifikasi tutupan/penggunaan lahan yaitu hutan, kebun atau perkebunan, ladang atau tegalan, lahan terbangun, lahan terbuka, sawah, semak belukar, tubuh air (sungai, bendungan). Citra yang dipakai pada penelitian ini adalah citra SPOT 4 untuk tahun 2007, sedangkan untuk tahun 2013 dan 2019 menggunakan citra SPOT 6.

Uji akurasi klasifikasi penggunaan lahan/penutupan lahan menggunakan 58 titik uji dengan metode sebaran purposive sampling. Berdasarkan analisis matriks kesalahan pada penelitian ini diperoleh nilai overall accuracy sebesar $88 \%$ dan kappa accuracy sebesar $86.5 \%$. Nilai overall accuracy pada umumnya memiliki nilai lebih tinggi dibandingkan kappa accuracy karena tidak memperhitungkan nilai uji yang salah interpretasi. Nilai kappa accuracy pada penelitian ini menunjukkan hasil interpretasi citra satelit termasuk dalam kategori sangat baik sehingga hasil klasifikasi dapat digunakan untuk analisa penggunaan lahan selanjutnya Peta tutupan/penggunaan lahan berdasarkan hasil klasifikasi penelitian disajikan pada Gambar 2 (tahun 2019) sementara proporsi luasan pada tutupan/penggunaan lahan disajikan pada Tabel 2 dan tutupan/perubahan penggunaan/tutupan lahan 2007, 2013, 2019 dapat dilihat pada Tabel 3.

Tabel 2 Penggunaan lahan 2007, 2013 dan 2019 Kabupaten Lampung Selatan

\begin{tabular}{lcccccc}
\hline \multicolumn{1}{c}{$\begin{array}{c}\text { Penggunaan/Tutupan } \\
\text { Lahan }\end{array}$} & \multicolumn{2}{c}{2007} & \multicolumn{2}{c}{2013} & \multicolumn{2}{c}{2019} \\
\cline { 2 - 7 } & Luas (ha) & $\%$ & Luas (ha) & $\%$ & Luas (ha) & $\%$ \\
\hline Hutan & 11415.2 & 5.27 & 11330.1 & 5.23 & 11095.7 & 5.12 \\
Kebun/Perkebunan & 76814.8 & 35.47 & 77998.7 & 36.02 & 78351.8 & 36.18 \\
Ladang/Tegalan & 50159.3 & 23.16 & 49116.4 & 22.68 & 48468.9 & 22.38 \\
Lahan Terbangun & 15695.3 & 7.25 & 16174.2 & 7.47 & 17729.9 & 8.19 \\
Lahan Terbuka & 1512.9 & 0.70 & 1797.1 & 0.83 & 2077.6 & 0.96 \\
Sawah & 45656.2 & 21.08 & 45390.9 & 20.96 & 44535.4 & 20.57 \\
Semak Belukar & 10048.6 & 4.64 & 9494.4 & 4.38 & 9035.9 & 4.17 \\
Tubuh Air & 5237.7 & 2.42 & 5238.0 & 2.42 & 5244.5 & 2.42 \\
\hline Jumlah & 216540 & 100 & 216540 & 100 & 216540 & 100 \\
\hline
\end{tabular}

Tabel 3 Perubahan penggunaan/tutupan lahan 2007-2019 Kabupaten Lampung Selatan

\begin{tabular}{lcccccc}
\hline \multicolumn{1}{c}{ Penggunaan/Tutupan } & \multicolumn{2}{c}{$2007-2013$} & \multicolumn{2}{c}{$2013-2019$} & \multicolumn{2}{c}{$2007-2019$} \\
\cline { 2 - 7 } \multicolumn{1}{c}{ Lahan } & -85 & -0.75 & -234 & -2.07 & -319 & -2.80 \\
\hline Hutan & 1184 & 1.54 & 353 & 0.45 & 1537 & 2.00 \\
Kebun/Perkebunan & -1043 & -2.08 & -648 & -1.32 & -1690 & -3.37 \\
Ladang/Tegalan & 479 & 3.05 & 1556 & 9.62 & 2035 & 12.96 \\
Lahan Terbangun & 284 & 18.79 & 281 & 15.61 & 565 & 37.33 \\
Lahan Terbuka & -265 & -0.58 & -855 & -1.88 & -1121 & -2.45 \\
Sawah & -554 & -5.52 & -459 & -4.83 & -1013 & -10.08 \\
Semak Belukar & 0 & 0.01 & 6 & 0.12 & 7 & 0.13 \\
Tubuh Air & & & & & & \\
\hline
\end{tabular}


Pada Tabel 2 menginformasikan bahwa penggunaan lahan terbesar di Kabupaten Lampung Selatan adalah perkebunan baik pada tahun 2007 sebesar 35.47\% maupun pada tahun 2019 sebesar $36.18 \%$ hal ini sejalan dengan PDRB Kabupaten Lampung Selatan dimana PDRB Kabupaten Lampung Selatan paling besar dihasilkan dari sektor pertanian yang di dalamnya terdapat sub sektor perkebunan. Tutupan/penggunaan lahan perkebunan yang naik sebesar 2\% dari tahun 2007 sampai dengan 2019. Hal ini menggambarkan bahwa pada tahun 2007 pada Kabupaten Lampung Selatan sudah ada campur tangan manusia namun tidak besar, sedangkan pada tahun 2019 dengan berbagai faktor sosial, ekonomi dan budaya yang terjadi seperti pertambahan jumlah penduduk, kebutuhan manusia akan pangan dan pemenuhan kebutuhan primer yang lainnya maka terjadi perubahan tutupan/penggunaan lahan dari hutan menjadi area bukan hutan. Intervensi pemerintah yang ingin meningkatkan nilai pendapatan daerah dengan hasil perkebunan juga akan mengakibatkan terjadinya perubahan tutupan/penggunaan lahan hutan menjadi perkebunan.

Perubahan penggunaan/tutupan lahan yang signifikan bertambah adalah lahan terbangun dimana lahan terbangun bertambah 479 ha pada tahun 2007 sampai 2013 sedangkan dari tahun 2013 sampai 2019 naik sebesar 1556 ha atau sekitar 9.62\%. Hal ini dapat terjadi akibat pembangunan masif dari pemerintah baik pemerintah pusat maupun pemerintah daerah. Pemerintah pusat membangun infrastruktur yang berakibat terjadi penggunaan/tutupan yang sangat signifikan ditambah dengan akses ke ibukota provinsi yang makin baik mengakibatkan konversi lahan menjadi lahan terbangun tidak dapat dihindarkan.

Sawah juga mengalami penurunan luas yang cukup signifikan dimana perubahan lahan sawah pada tahun 2007-2013 berkurang sebesar 265 ha, sedangkan pada tahun 2013-2019 berkurang 855 ha, diakibatkan pada rentang tahun 2013-2017 Kabupaten Lampung Selatan belum ditetapkan Peraturan Daerah mengenai kawasan Lahan Pertanian Pangan Berkelanjutan (LP2B) sesuai dengan Undang-Undang Nomor 41 tahun 2009 tentang Lahan Pertanian Pangan Berkelanjutan.

Perubahan tutupan/penggunaan lahan semak belukar berkurang pada rentang tahun 2007 sampai tahun 2013 sebesar 554 ha, sedangkan pada rentang tahun 2013 sampai tahun 2019 berkurang sebesar 459 ha. Penggunaan/tutupan lahan semak belukar 2007-2019 sebesar 1013 ha. Lahan terbuka mengalami penambahan penggunaan/tutupan lahan mengalami persentase terbesar sebesar 37.33\% namun dalam luasan tutupan lahan ini hanya sebesar 565 ha dalam rentang waktu 2007-2019.

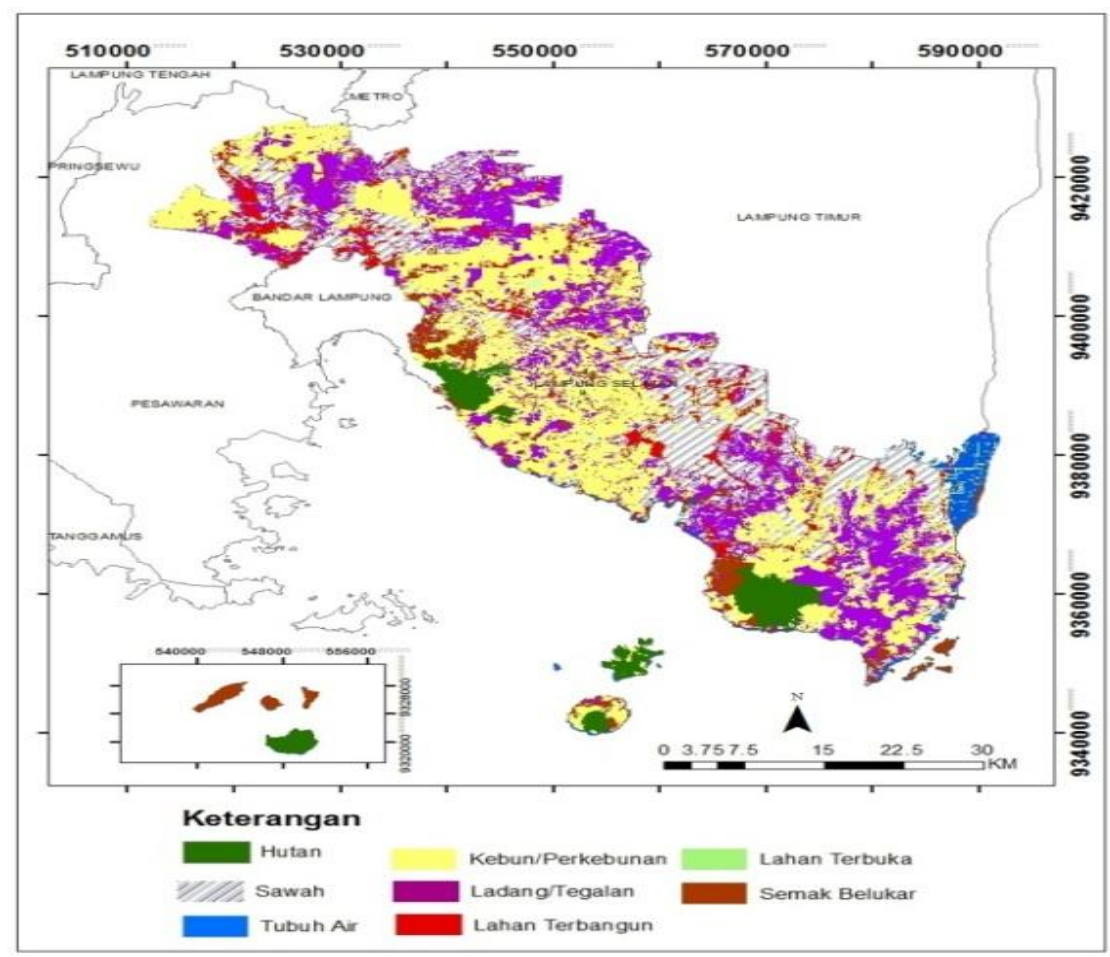

Gambar 2 Peta penggunaan/tutupan lahan Lampung Selatan Tahun 2019 


\section{Perubahan Tutupan/Penggunaan Lahan}

Model perubahan tutupan/penggunaan lahan pada penelitian ini menggunakan dua titik tahun, yaitu tahun 2007 sebagai titik dasar dan tahun 2019 sebagai titik akhir dari penelitian. Pada tahap awal yaitu tahap analisis perubahan penggunaan lahan dari tahun 2007 ke tahun 2019 yang menghasilkan suatu grafik penambahan dan penurunan luas dalam tiap tutupan/penggunaan lahan (Gambar 3) sedangkan matriks perubahan lahan tersaji pada Tabel 4. Warna ungu yang terdapat dalam grafik menggambarkan bahwa terjadi penurunan luasan dalam suatu tutupan/penggunaan lahan, sedangkan warna hijau menginformasikan bahwa suatu lahan mengalami penambahan luasan. Sedangkan pada Tabel 4 menggambarkan transisi antara tutupan dan penggunaan lahan.

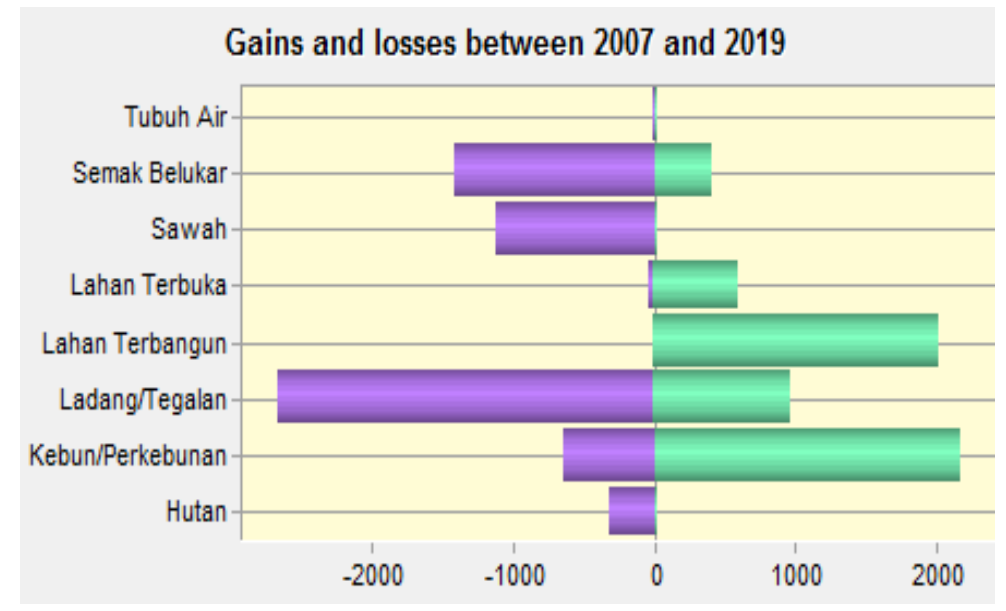

Gambar 3 Perubahan penggunaan/tutupan lahan 2007-2019

Tabel 4 Matriks transisi perubahan tutupan/penggunaan lahan tahun 2007 dan 2019

\begin{tabular}{ccccccccc}
\hline PL/TL & \multicolumn{7}{c}{2019} \\
\cline { 2 - 9 } 2013 & 1 & 2 & 3 & 4 & 5 & 6 & 7 & 8 \\
\hline 1 & 0.8437 & 0.0643 & 0.0023 & 0 & 0.0656 & 0 & 0.0241 & 0 \\
\hline 2 & 0 & 0.8479 & 0.0001 & 0.1518 & 0 & 0.0002 & 0 & 0 \\
\hline 3 & 0 & 0.1487 & 0.8277 & 0.0216 & 0.0004 & 0.0001 & 0.0016 & 0 \\
\hline 4 & 0.01 & 0.01 & 0.01 & 0.93 & 0.01 & 0.01 & 0.01 & 0.01 \\
\hline 5 & 0 & 0 & 0 & 0.1524 & 0.8476 & 0 & 0 & 0 \\
\hline 6 & 0 & 0.0502 & 0.0527 & 0.0438 & 0 & 0.845 & 0.0077 & 0.0005 \\
\hline 7 & 0 & 0.039 & 0.0615 & 0.0153 & 0.0843 & 0 & 0.7998 & 0 \\
\hline 8 & 0 & 0 & 0 & 0.1201 & 0.03 & 0 & 0 & 0.8499 \\
\hline
\end{tabular}

Keterangan: 1. Hutan, 2. Kebun atau Perkebunan 3. Ladang atau Tegalan 4. Lahan Terbangun, 5. Lahan Terbuka, 6. Sawah, 7. Semak Belukar, 8. Tubuh Air

Perubahan tutupan/penggunaan lahan yang terjadi pada sawah dan hutan sangat signifikan karena tidak ada penambahan yang terjadi sejak tahun 2007 sampai dengan 2019. Perubahan penggunaan lahan yang terjadi pada lahan sawah sebesar 1121 ha, perubahan penggunaan/tutupan lahan yang terjadi pada sawah ini terbanyak berubah menjadi lahan terbangun dimana lahan sawah yang terkonversi menjadi lahan terbangun sebanyak 510 ha $(45 \%)$. Perubahan yang terjadi pada hutan menjadi penggunaan lahan selain hutan sebanyak 320 ha dimana yang berubah adalah hutan yang tidak termasuk dalam kawasan hutan yang ditetapkan pemerintah. Hutan yang terkonversi menjadi perkebunan merupakan konversi hutan yang paling banyak adalah kebun/perkebunan dibandingkan dengan kelas penggunaan lahan yang lain ada didalam kelas penggunaan lahan yang terdapat pada penelitian ini. 
Lahan terbangun merupakan kelas penggunaan lahan yang tidak mengalami pengurangan luas namun mengalami penambahan luas. Penambahan luas lahan terbangun menjadi sebesar 2034 ha, lahan terbangun tersebut mengalami penambahan luas terbesar dari ladang/tegalan sebesar 32\%, kebun/perkebunan sebesar $31 \%$ dan sawah sebesar 25\%. Hal ini tidak terelakkan dalam rangka memenuhi kebutuhan ruang untuk pembangunan dan juga pesatnya laju pertumbuhan penduduk, pertumbuhan ekonomi, meningkatkan kebutuhan lahan untuk permukiman dan aktivitas manusia.

Ladang/tegalan merupakan kelas pengunaan lahan yang terluas mengalami perubahan menjadi lahan terbangun. Hal ini disebabkan oleh aksesbilitas jalan dan sarana prasarana pada ladang/tegalan yang baik serta dekat dengan pemukiman yang ada. Kebun/perkebunan juga merupakan kelas penggunaan lahan yang banyak mengalami perubahan lahan menjadi lahan terbangun hal ini disebabkan kebun perkebunan membuat kawasan industri sehingga perkebunan tersebut menjadi pabrik dalam hal pengolahan makanan dari kebun tersebut. Sawah menjadi kelas penggunaan yang berubah penggunaannya menjadi lahan terbangun namun pada kelas penggunaan lahan sawah pada rentang 2007-2019 belum mempunyai aksesbilitas jalan dan masih didaerah yang jauh dari pemukiman padat penduduk.

\section{Validasi Model}

Pemodelan yang dilakukan terlebih dahulu divalidasi untuk melihat apakah model tersebut dapat digunakan untuk memprediksi tutupan/penggunaan lahan pada tahun yang akan datang. Validasi dilakukan dengan menyandingkan hasil dari prediksi tutupan/penggunaan lahan tahun 2019 dengan peta penggunaan lahan aktual tahun 2019 (Gambar 4).

Prediksi tutupan/penggunaan lahan pada tahun 2019 didapat dari hasil analisis markov chain dengan memanfaatkan data tutupan/penggunaan lahan tahun 2007 sebagai tahun dasar/awal dan tutupan/penggunaan lahan pada tahun 2013 sebagai tahun kedua. Hasil prediksi penggunaan lahan tahun 2019 disandingkan dengan tutupan/penggunaan lahan tahun 2019 hasil interpretasi dengan menggunakan metode crosstab (tabulasi silang). Perlu diketahui bahwa nilai akurasi kappa atau nilai kecocokan (kemiripan) antara jumlah kolom dan baris maksimal adalah bernilai 1.00 .

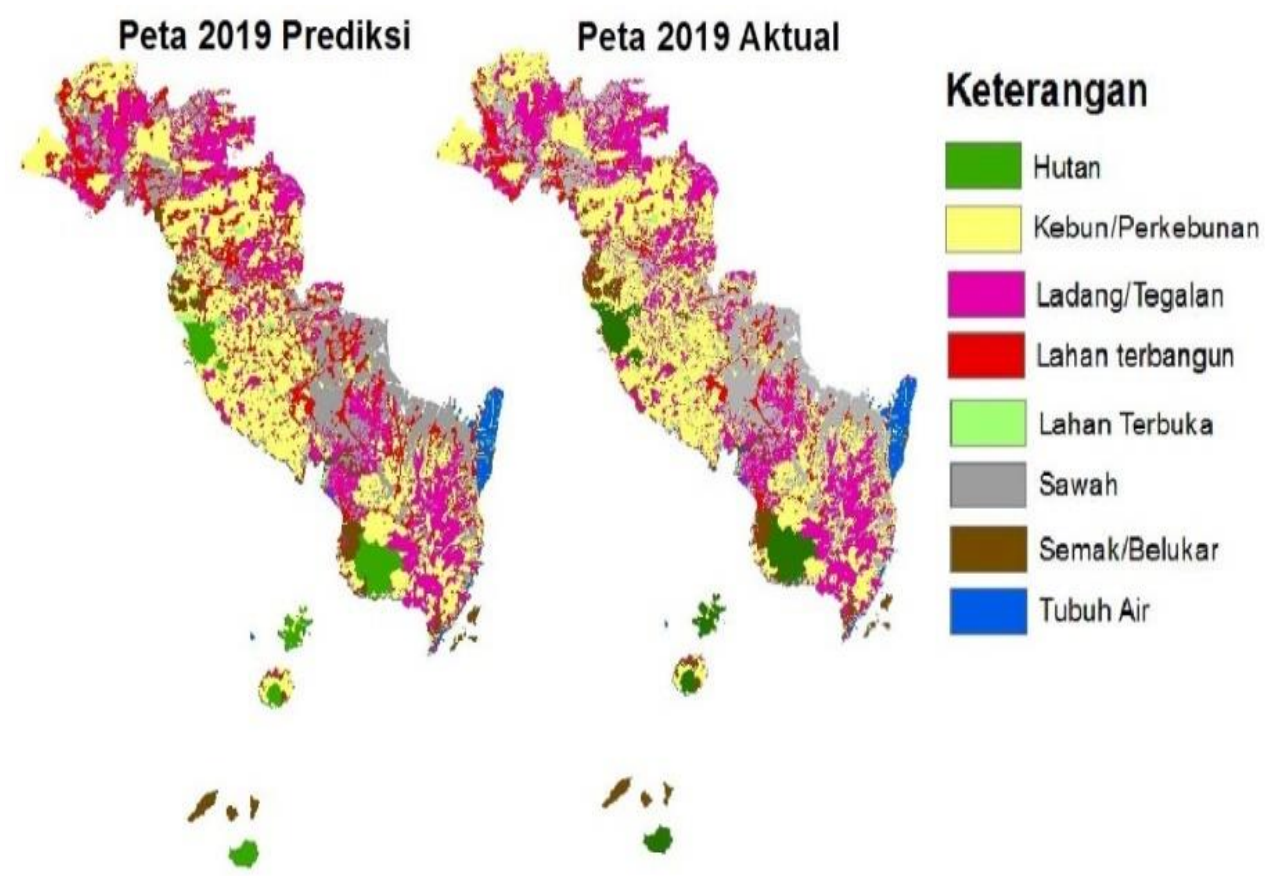

Gambar 4 Peta penggunaan lahan prediksi tahun 2019 dan peta penggunaan lahan 2019 aktual 
Menurut Altman (1991) dalam Kubangun (2015) nilai akurasi kappa 0.81-1.00 menunjukkan adanya kecocokan yang sangat baik, nilai akurasi kappa 0.61-0.80 adalah kecocokan baik, 0.41-0.60 adalah kecocokan sedang, 0.21-0.40 adalah kecocokan kurang dari sedang, dan nilai <0.21 dikatakan kecocokan buruk. Berdasarkan hasil validasi untuk proyeksi ini menunjukkan bahwa nilai kappa yang diperoleh adalah sebesar 0.9469. Nilai ini menunjukkan bahwa pemodelan ini tergolong mempunyai kesepakatan atau kecocokan yang sangat baik terhadap kondisi eksisting penutupan/penggunaan lahan tahun 2019. Tingginya nilai dari akurasi kappa tersebut, maka model dari hasil yang telah dilakukan dapat digunakan untuk memprediksi pola persebaran dan luasan tutupan/penggunaan lahan untuk dapat prediksi tutupan/penggunaan lahan pada tahun 2031, yaitu dengan berdasarkan pada trend historis yang telah terjadi pada proyeksi pemodelan tersebut.

\section{Prediksi Tutupan/Penggunaan Lahan Kabupaten Lampung Selatan pada Tahun 2031}

Prediksi yang telah dilakukan pada penelitian ini dengan menggunakan satu jenis model, yaitu model Bussiness As Usual dimana pada model ini perubahan mengikuti pola histori yang telah terjadi dari tahun sebelumnya, metode prediksi tutupan/penggunaan lahan pada tahun 2031 dilakukan dengan metode yang sama yaitu Marcov Chain. Matriks peluang terjadinya perubahan penggunaan lahan di tahun 2031 untuk skenario Bussiness As Usual ditunjukkan dalam Tabel 5. Peta dikonversi menjadi bentuk raster dengan ukuran piksel 30x30 meter. Data-data ini sebagai input dalam membangun model prediksi tutupan/penggunaan lahan pada aplikasi CA-Markov. Perbedaan format data vektor dan raster akan menyebabkan selisih luas walaupun secara keseluruhan tidak berbeda signifikan. Input pertama dalam pembuatan model prediksi tutupan/penggunaan lahan tahun 2031 adalah peta tutupan/penggunaan lahan tahun 2019 sebagai basemap kondisi awal. Input kedua adalah matriks area transisi yang didapat dari Markov Chain analisis peta tahun 2007-2019. Analisis ini menggunakan 12 kali iterasi, dimana 1 kali iterasi mewakili 1 tahun perubahan.

Perubahan tutupan/penggunaan lahan antara tahun 2007 dan tahun 2019 digunakan sebagai input dalam analisis Markov Chain. Hasil analisis tersebut adalah matriks probabilitas dan matriks transisi area. Nilai 0 menunjukkan tidak terjadi perubahan tutupan/penggunaan lahan dari tutupan/penggunaan lahan sebelumnya (awal) menjadi tutupan/penggunaan lahan lainnya di akhir periode transisi. Nilai-nilai matriks tegak lurus diagonal (baris-kolom) menunjukkan luas tutupan/penggunaan lahan yang tidak berubah (tetap sebagai tutupan/penggunaan lahan yang sama). Nilai-nilai matriks ke samping kiri-kanan kolom dalam satu baris menunjukan nilai perubahan dan luas pada tutupan/penggunaan di kolom tersebut.

Proyeksi perubahan lahan hutan yang terbesar adalah menjadi kebun/perkebunan adalah sebesar 1141 ha dan jumlah proyeksi hutan menjadi 9437 ha. Kebun/perkebunan diproyeksikan akan mengalami perubahan lahan pada tahun 2031 yang terbesar menjadi lahan terbangun 11900 ha dan jumlah prediksi penggunaan lahan untuk kebun/perkebunan menjadi sebesar 75167 ha pada tahun 2031. Perubahan lahan proyeksi untuk ladang/tegalan menjadi kebun/perkebunan sebesar 5767 ha dan jumlah luasan prediksi lahan ladang/tegalan pada tahun 2031 menjadi 42171 ha.

Lahan terbangun merupakan penggunaan lahan yang terjadi penambahan yang signifikan antara tahun 2019-2031, lahan terbangun diprediksi akan menjadi 34810 ha terjadi penambahan 17808 ha dari tahun 20192031. Penambahan luasan lahan terbangun diakibatkan peningkatan infrastruktur yang masif yang mengakibatkan peningkatan ekonomi sehingga harus merubah lahan dari non terbangun menjadi lahan terbangun.

Pada Tabel 5 prediksi perubahan lahan tahun 2019-2031 pengurangan lahan sawah sebesar $16.2 \%$ hal ini diakibatkan peningkatan infrastruktur di daerah tutupan/penggunaan lahan sawah. Pengurangan ini juga diakibatkan peningkatan pertumbuhan penduduk yang terjadi di Kabupaten Lampung Selatan.

Prediksi penggunaan lahan terbuka juga terjadi penambahan luasan pada tahun 2031, perubahan luasan lahan terbuka menjadi 3875 ha terjadi kenaikan sebesar 86.5\% dari tahun 2019 yang hanya sebesar 2078 ha. Prediksi perubahan lahan sawah juga terjadi pada tahun 2031, lahan sawah diprediksi akan mengalami penurunan menjadi 37317 ha terjadi penurunan 7218 ha (-13.24 ha) pada tahun 2031. Perubahan lahan sawah terjadi yang terbesar menjadi lahan terbangun yaitu sebesar 1298 ha. 
Semak belukar juga mengalami perubahan luasan pada tahun 2031 menjadi 8945 ha terjadi perubahan luasan sebesar 91 ha. Tubuh air yang terdiri dari sungai, tambak, bendungan dan juga embung terjadi pengurangan luasan menjadi 4839 ha, mengalami pengurangan sebesar 405 ha pada tahun 2031. Perubahan luasan dapat dilihat pada Tabel 5 dan peta prediksi penggunaan lahan dapat dilihat pada Gambar 5.

Tabel 5 Prediksi perubahan penggunaan lahan 2019-2031

\begin{tabular}{lcccccc}
\hline \multirow{2}{*}{ Penggunaan Lahan } & \multicolumn{2}{c}{2019} & \multicolumn{2}{c}{2031} & \multicolumn{2}{c}{$2019-2031$} \\
\cline { 2 - 7 } & Luas (ha) & $\%$ & Luas (ha) & $\%$ & $+/-$ & $\%$ \\
\hline Hutan & 11096 & 5.12 & 9437 & 4.36 & -1659 & -14.9 \\
\hline Kebun/ Perkebunan & 78352 & 36.18 & 75167 & 34.71 & -3185 & -4.1 \\
\hline Ladang/ tegalan & 48469 & 22.38 & 42171 & 19.47 & -6298 & -13.0 \\
\hline Lahan Terbangun & 17730 & 8.19 & 34810 & 16.07 & 17080 & 96.3 \\
\hline Lahan Terbuka & 2078 & 0.96 & 3875 & 1.79 & 1797 & 86.5 \\
\hline Sawah & 44535 & 20.57 & 37317 & 17.23 & -7218 & -16.2 \\
\hline Semak & 9036 & 4.17 & 8945 & 4.13 & -91 & -1.0 \\
\hline Tubuh Air & 5245 & 2.42 & 4839 & 2.23 & -405 & -7.7 \\
\hline Jumlah & 216540 & 100.00 & 216540 & 100 & & \\
\hline
\end{tabular}

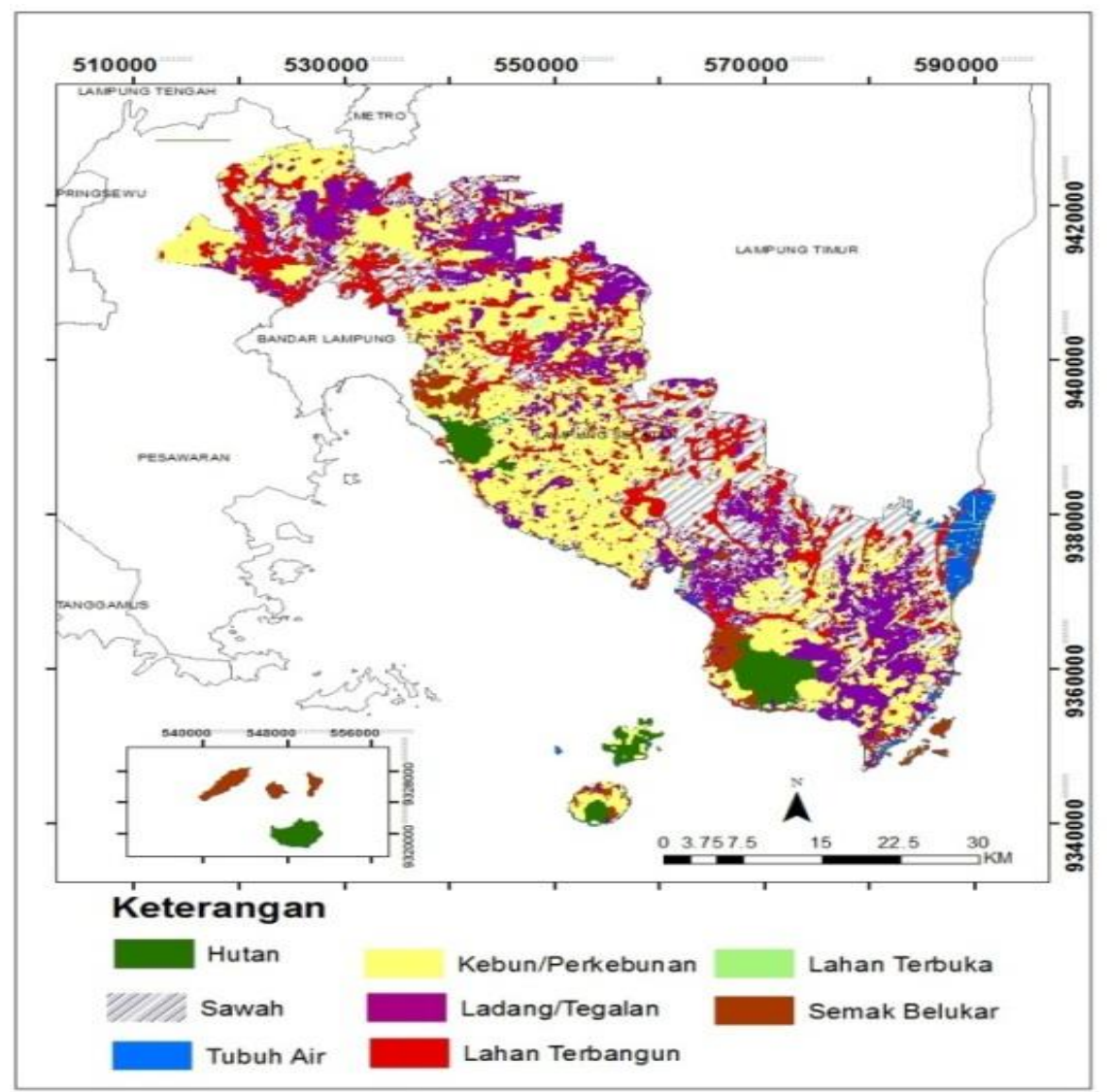

Gambar 5 Peta prediksi penggunaan/tutupan lahan tahun 2031

Prediksi ini dilakukan mengikuti pola histori yang telah terjadi antara tahun 2007, 2013 dan tahun 2019. Prediksi untuk penelitian selanjutnya ada baiknya digunakan menggunakan skenario konservasi. Skenario konservasi yang dimaksud adalah dengan mempertahankan penggunaan/tutupan lahan sawah dan mempertahankan penggunaan/tutupan lahan hutan. 


\section{KESIMPULAN}

Hasil penelitian ini mendapatkan nilai kappa sebesar 86.5\% untuk tutupan/penggunaan lahan tahun 2019. Sedangkan validasi model didapatkan nilai kappa sebesar $94.6 \%$ dan dapat untuk model prediksi perubahan lahan sampai tahun 2031. Perubahan tutupan/penggunaan lahan di Kabupaten Lampung Selatan dari tahun 2007 sampai tahun 2019 bertambah luasan paling tinggi adalah lahan terbangun dan kebun/perkebunan. Tutupan/penggunaan lahan yang mengalami penurunan luasan cukup besar adalah ladang/tegalan berkurang dan sawah. Hal ini diakibatkan perkembangan infrastruktur yang begitu masif di Kabupaten Lampung Selatan. Tutupan/penggunaan lahan sawah adalah penggunaan lahan yang berkurang paling banyak.

\section{UCAPAN TERIMA KASIH}

Penulis berterima kasih kepada Instiut Pertanian Bogor, Pemerintah Provinsi Lampung dan juga kepada Pemerintah Kabupaten Lampung Selatan yang telah mendukung penelitian ini. Terima kasih pula diucapkan kepada Bappenas, yang telah memberikan dukungan melalui program bantuan penelitian Pusbindiklatren Bappenas.

\section{DAFTAR PUSTAKA}

Hardjowigeno S, Widiatmaka. 2015. Evaluasi Lahan dan Perencanaan Tata Guna Lahan. Yogyakarta (ID): Gadjah Mada University Press.

Hedge NP, Muralikrishna IV, Chalapatirao KV. 2008. Settlement growth prediction using neural network and cellular automata. Journal of Theoretical and Applied Information Technology. 419-428.

Hermawan E. 2011. Modeling and simulating spatial distribution pattern of urban growth using integration of GIS and Cellular automata [tesis]. Bogor (ID): Institut Pertanian Bogor.

Jie Z. 2010. Accuracy assessment and uncertainty analysis of spatial explicit modeling for land use/cover change and urbanization: A case in Beijing metropolitan area. Science China Earth Sciences. 53(2): $173-80$.

Kamusoko C, Aniya M, Adi B, Manjoro M. 2009. Rural sustainability under threat in Zim-babwe - Simulation of future land use/cover changes in the Bindura district based on the Markov-cellular automata model. Journal Applied Geography. 29: 435-447.

Kubangun SH. 2015. Model spasial bahaya lahan kritis di Kabupaten Bogor, Cianjur, dan Sukabumi [tesis]. Bogor (ID): Institut Pertanian Bogor.

Lillesand TM, Kiefer RW. 1994. Penginderaan Jauh dan Interpretasi Citra. Yogyakarta (ID): Gadjah Mada University Press.

Mas JF, Kolb M, Paeglow M, Olmedo MC, Houet T. 2013. Modeling land use/cover change changes: a comparison of conceptual approachs and softwares. Environmental Modeling and Software. 51: 94-111.

Mondal Md S, Sharma N, Garg PK, Kappas M. 2016. Statistical independence test and validation of CA Markov land use land cover (LULC) prediction results. The Egyptian Journal of Remote Sensing and Space Sciences. 19: 259-272.

Munibah K. 2008. Model spasial perubahan penggunaan lahan dan arahan penggunaan lahan berwawasan lingkungan (studi kasus DAS Cidanau, Provinsi Banten) [disertasi]. Bogor (ID): Institut Pertanian Bogor.

Nouri J, Gharagozlou A, Arjmandi R. 2014. Predicting urban land use changes using a CA-Markov Model. Arabian Journal for Science and Engineering. doi: 10.1007/s13369-014-1119-2.

Riccioli F, Asmar TE, Asmar JPE, Fratini R. 2013. Use of cellular automata in the study of variables involved in land use changes: An application in the wine production sector. Environ Monit Assess. 185: 53615374. 
Rotinsulu W, Walangitan H, Ahmad A. 2018. Analisis perubahan tutupan lahan DAS Tondano, Sulawesi Utara selama periode tahun 2002 dan 2015. Jurnal Pengelolaan Sumberdaya Alam dan Lingkungan. 8(2): 161-169.

Verburg PH, Veldkamp TA, Bouma J. 1999. Land use change under conditions of high population pressure: the case of Java. Global Environmental Change. 9(4): 303-312.

Wang SQ, Zheng XQ, Zang XB. 2012. Accuracy assessments of land use change simulation based on Markovcellular automata model. Procedia Environmental Sciences. 13: 1238-1245.

Widiatmaka, Ambarwulan W, Purwanto MYJ, Setiawan Y, Effendi H. 2015. Daya dukung lingkungan berbasis kemampuan lahan di Tuban, Jawa Timur. Jurnal Manusia Dan Lingkungan. 22(2): 247-259.

Xin Y, Xin-Qi Z, Li-Na Lv. 2012. A spatiotemporal model of land use change based on ant colony optimization, Markov chain and cellular automata. Journal of Ecological Modelling. 1: 11-19.

Yusuf SM, Murtilaksono K, Hidayat Y, Suharnoto Y. 2018. Analisis dan prediksi perubahan tutupan lahan di DAS Citarum Hulu. Jurnal Pengelolaan Sumberdaya Alam dan Lingkungan. 8(3): 365-375. 